\title{
8
}
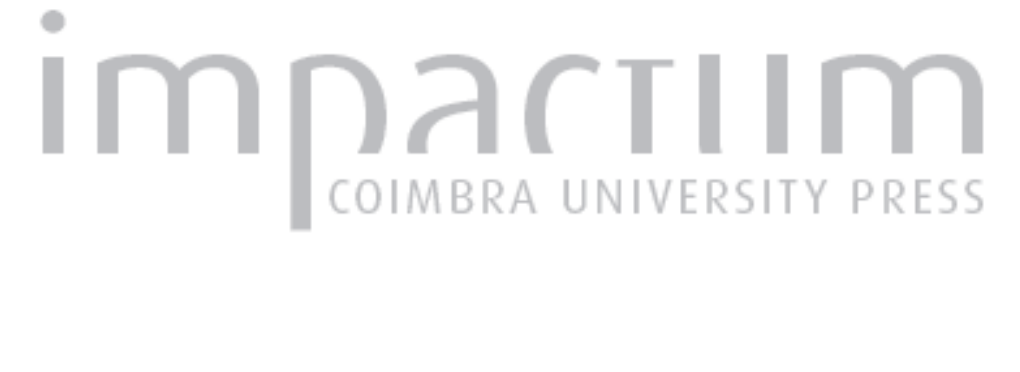

\section{Estado autoritário e violencia no Brasil}

Autor(es): $\quad$ Filho, Nilson Borges; Filgueira, Fernando Publicado por: Instituto de História Económica e Social; Imprensa da Universidade de

URL persistente:

URI:http://hdl.handle.net/10316.2/44497

DOI:

DOI:https://doi.org/10.14195/0870-4147_37_5

Accessed : $\quad$ 26-Apr-2023 12:39:13

A navegação consulta e descarregamento dos títulos inseridos nas Bibliotecas Digitais UC Digitalis, UC Pombalina e UC Impactum, pressupõem a aceitação plena e sem reservas dos Termos e Condições de Uso destas Bibliotecas Digitais, disponíveis em https://digitalis.uc.pt/pt-pt/termos.

Conforme exposto nos referidos Termos e Condições de Uso, o descarregamento de títulos de acesso restrito requer uma licença válida de autorização devendo o utilizador aceder ao(s) documento(s) a partir de um endereço de IP da instituição detentora da supramencionada licença.

Ao utilizador é apenas permitido o descarregamento para uso pessoal, pelo que o emprego do(s) título(s) descarregado(s) para outro fim, designadamente comercial, carece de autorização do respetivo autor ou editor da obra.

Na medida em que todas as obras da UC Digitalis se encontram protegidas pelo Código do Direito de Autor e Direitos Conexos e demais legislação aplicável, toda a cópia, parcial ou total, deste documento, nos casos em que é legalmente admitida, deverá conter ou fazer-se acompanhar por este aviso.

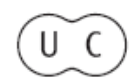




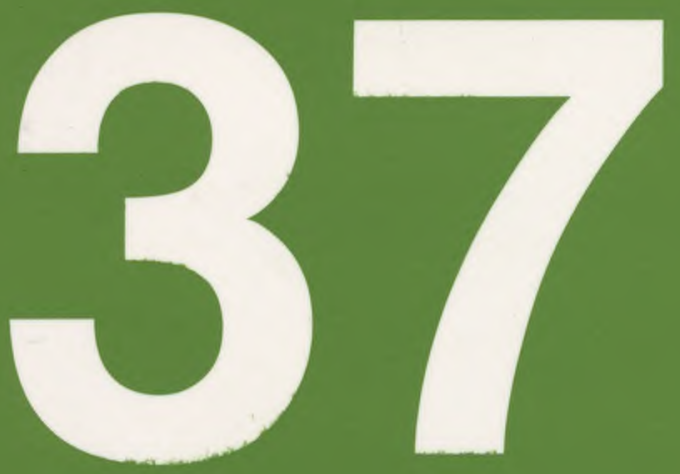

Revista Portuguesa de História

Faculdade de Letras da Universidade de Coimbra Instituto de Historia Econónica e Samial

Coimbra 05 


\section{Estado Autoritário e Violencia no Brasil}

\section{Cenário 1. Reconstruindo a História}

Há diversas formas de se contar a história, sobretudo quando se trata do Brasil. Vários enfoques podem ser oferecidos sobre determinados períodos, principalmente quando deles resultaram muitas dores sob o efeito da repressão política e da violência estatal. Inúmeros são os trabalhos que tratam da escalada repressiva no Brasil República em dois momentos importantes da sua história, como no Estado Novo e durante o regime militar que se instalou a partir de 31 de março de 1964.

Todos esses trabalhos que versam sobre tais momentos foram tratados, em maior número e densidade, pela pesquisa acadêmica ou por alguns memorialistas e protagonistas de então. A busca por fontes primárias era difícil e o acesso a ***

* Doutor em direito do Estado pela UFSC, pós-doutor em direito público pela Universidade de Coimbra, ex-professor da UFSC e da UFMG, coordenador e professor de Ciência Política da Faculdade Metodista Granbery.

** Doutorando em Ciência Política no Instituto Universitário de Pesquisas do Rio de Janeiro (IUPERJ). Mestre em Ciência Política pela Universidade Federal de Minas Gerais (UFMG). Professor de Sociologia Jurídica da Faculdade Metodista Granbery. 
essas mesmas fontes estava direcionado a um público privilegiado, ou seja, aos brasilianistas. Mesmo assim, um certo número reduzido de acadêmicos conseguiu, com muito esforço, produzir um leque de obras determinantes para se conhecer os dois períodos mais agonizantes do autoritarismo brasileiro e da violência praticada pelo Estado.

Por outro lado, além da academia, a história também pode ser contada pela crónica política e pelo jornalismo crítico, investigativo e independente. No Brasil de hoje, alguns acontecimentos de ontem estão sendo reconstruídos por análises jornalísticas, resultantes de uma investigação documental promissora, recompondo a memória nacional. O resultado dessas, vamos dizer assim, "reportagens" investigativas da imprensa brasileira foi o de nos oferecer um quadro inédito dos acontecimentos ocorridos no regime estado-novista de Getúlio Vargas, de 1937 a 1945, e no período da República dos Generais, de 1964 a 1985.

A história que aqui está sendo contada evoca para si o direito de dar "ouvidos" aos protagonistas desses períodos, sejam eles sujeitos coletivos ou singulares. O pensamento autoritário dos intelectuais orgânicos brasileiros, o idealismo conservador e excludente das elites formadas na mística do poder em nome da Nação, a insensibilidade à democracia dos ideólogos dos regimes de exceção, a truculência da violência fardada, justamente com os protagonistas singulares, democratas ou não, fornecerão a "base de dados" para esse novo olhar sobre os fundamentos do autoritarismo implantado no Brasil desde sempre.

Nos últimos três anos têm surgido novos - porém antigos - documentos sobre o Estado Novo e sobre o Regime Militar pós-64. A origem é das mais diversas: das organizações que pensaram ou construíram esses períodos, das organizações que combateram esses regimes, dos órgãos de repressão, dos acervos particulares, dos arquivos públicos e até mesmo dos "espiões" arrependidos. Quando se pensava que tudo havia sido dito sobre o período fascista de Vargas, eis que surgem documentos públicos tratando sobre matéria que se dizia esgotada: as intenções e ações "germanófilas" de Getúlio. Já sobre o golpe militar e o regime dos generais, desde o início dos anos de 1980, com a publicação de memórias, biografias e autobiografías de militantes dos dois lados, até os dias de hoje, com a publicação de livros de jornalistas e teses acadêmicas, vez por outra aportam nas livrarias obras que nos dizem que muito ainda está para ser contado e que a história recente brasileira permanece em construção, ou, a bem dizer, em reconstrução. Assim, a memória recente do país vai sendo construída, ao mesmo tempo em que o Brasil vivia ou vive o desafio de construir a democracia (Rollemberg, 2003:45). Parece que a vocação brasileira é estar sempre enfrentando desafios para a construção e para a consolidação da democracia. Foi assim a partir de 1946, com o encerramento do Estado Novo e a promulgação de uma 
nova Constituição; está sendo assim, ainda agora, com a Constituição de 1988 e com um governo que, saído das bases sindicais, pretende ser democrático.

$\mathrm{Na}$ verdade, uma parcela significativa da história política brasileira é, ainda, nos tempos de agora, "um segredo bem guardado" (Figueiredo, 2005:13), sobretudo quando se trata dos militares, seus generais e seus apêndices organizacionais como, por exemplo, os órgãos de informação - o Conselho de Defesa Nacional e o Serviço Nacional de Informação - gestores da violência estatal nos momentos do autoritarismo explícito no país.

O presente artigo, que trata sobre autoritarismo e violência no Brasil, cobrirá os acontecimentos políticos e sócio-econômicos ocorridos em dois períodos da história brasileira. Primeiro, de 1937 a 1945, quando da vigência do Estado Novo, patrocinado pelo presidente da República Getúlio Vargas, e por seus generais de plantão, Dutra e Góes Monteiro, ministro da Guerra e chefe do Estado-Maior do Exército, respectivamente. Em segundo lugar, de 1964 a 1985, período conhecido como regime militar. A idéia inicial é demonstrar como se forma o pensamento autoritário brasileiro e, a partir desse pensamento, como a violência estatal se operacionaliza nestes períodos, sendo ela um mecanismo mediante o qual o Estado se coloca acima das classes sociais, construindo a Nação a partir do medo provocado por essa violência. Em um segundo momento procura-se demonstrar como o Estado brasileiro se utilizou desse pensamento autoritário e da violência institucionalizada derivada dele como mecanismos de reprodução ideológica, porém não atrelada a qualquer classe social presente na arena política, configurando uma peculiaridade histórica que atravessa a formação brasileira no século XX.

\section{Cenário 2. Demarcando Conceitos}

Antes de ingressar no mérito deste ensaio, a temática que dele se projeta para um melhor entendimento do conceito de autoritarismo pressupõe alguns esclarecimentos prévios, sobretudo para distingui-lo de outros conceitos, muitas vezes tidos como sinónimos, mas que encobrem diferenças processuais no âmbito da sociedade, como ditadura e totalitarismo. Tal análise não se restringe apenas ao campo doutrinário, focalizando-se, em especial, no caso concreto brasileiro. Embora alguns autores pequem pela generalização, o autoritarismo implantado no país carrega determinadas características que o distingue, inclusive, de outros regimes autoritários latino-americanos. Portanto, à medida que se vai tentando apurar o conceito de autoritarismo na esfera da concretude brasileira, mais próximo vai se chegar ao principal protagonista dos diversos momentos e períodos de estado de exceção vivenciados no decorrer da história política do país: os militares. 
Contudo, é importante assinalar que o poder civil sempre se negou a considerar o aparelho militar como ator principal no espectro político brasileiro. Entender que as Forças Armadas foram meros atores coadjuvantes ao longo da história é desconhecer o seu papel tutelar, quando, antes de 1964, estabeleceram os limites de até onde o poder civil poderia atuar. Já a partir de 1964, os militares passam a se atribuir uma capacidade decisória própria, que os transforma em principal ator político, com autonomia relativa perante o Estado (Ferreira, 2000:11-12). É claro que quando o estamento militar age politicamente, deve-se considerar que ele não fala apenas em seu nome, mas, sobretudo, em nome de grupos, tanto de grupos civis quanto de grupos militares, que se arrogam o papel de arautos da Nação. Em todos os momentos em que as Forças Armadas brasileiras tentaram agir por conta própria, sem uma aliança prévia com as elites civis, o pronunciamento militar transformou-se numa simples quartelada. Porém, quando essa aliança se faz de forma clara e objetiva, como aconteceu em 1937 e 1964, o sucesso para a implantação de um regime autoritário está plenamente garantido, sem muito esforço de ordem operacional. Tanto no golpe do Estado Novo quanto no golpe de 1964 as reações aos movimentos foram mínimas, sendo que, em nenhum momento, colocaram em risco as ações golpistas. Faz-se mister assinalar, a bem da verdade, que a tese que apresenta as Forças Armadas brasileiras como instrumento do poder civil (Coelho, 1976: 18-19), convocadas para dar apoio aos projetos da elite política, não tem a menor sustentação empírica, principalmente porque se sabe que o aparelho militar tem características que o colocam em vantagem sobre quaisquer organizações civis: superioridade em organização, um sistema simbólico altamente eficiente e o monopólio das armas (Góes, 1984: 362).

Retomando ao início deste cenário, é preciso deixar bem clara a distinção entre regimes autoritários e regimes totalitários e ditatoriais, sejam eles de esquerda ou de direita. Em primeiro lugar deve-se traçar o conceito de autoritarismo, para, num segundo momento, caracterizar o autoritarismo brasileiro: seu pensamento e sua ação política. Convém salientar que estabelecer uma definição de autoritarismo envolve uma certa dificuldade conceituai (Aquino, 2004: 55), a começar pela crítica à sua excessiva amplitude. Essa excessiva amplitude pode ser vista, também, como um ponto favorável considerando os diversos tipos de regimes autoritários que existiram - e ainda existem - ao longo da história de uma parcela considerável de países ao redor do mundo.

Os regimes autoritários nasceram das condições políticas vigentes no século XX que, grosso modo, pode-se "caracterizar, negativamente, por menos investimentos em todas as esferas da vida social; pela inexistência de uma simbiose entre partido político e Estado, sendo o primeiro, quando existente, dependente do 
último; pela restrição à mobilização das massas" (Fausto, 2001a: 8). Se existe urna característica dos regimes autoritários que alcança quase que a unanimidade entre os doutrinadores e analistas políticos é a sua relativa autonomia, que preserva a sociedade em relação ao Estado, isto é, a existência de urna certa tolerancia de pensamento. No caso brasileiro, específicamente pós-64, o partido de oposição era tolerado pelo regime, desde que não levantasse a bandeira do seu desmonte - do regime. François Furet, citado por Boris Fausto, entende que, na prática, não é fácil distinguir regimes totalitários de regimes autoritários, isto porque lidamos, em ambos os casos, com tipos ideais, cujos traços não estão integralmente presentes em várias situações do cotidiano (Fausto, 2001a: 8).

A rigor, não se pode abandonar a idéia da existência de alguma similitude entre totalitarismo e autoritarismo, mas acreditamos que prevaleça a tese de que o conceito de autoritarismo não se restringe por determinadas características presentes nos conceitos de totalitarismo - a necessidade de um partido de massa responsável por uma ampla mobilização na sociedade - e de ditadura - a premência de se utilizar de um ditador carismático ou de um partido que agregue em seu projeto político algumas demandas populistas. Essa análise distintiva (Aquino, 2004: 55), que abriga uma boa parte dos conceitos formuladores de regimes autoritários reflete, de certa maneira, algumas especificidades dos regimes autoritários de perfil militar, como no caso brasileiro (1937 e 1964).

Mas é em Juan Linz e O'Donnell que se vai encontrar uma tipología para os regimes autoritários. A tipología que aponta para um regime autoritário burocrático-militar, no entender de Linz, reconhecia a presença de uma fusão de oficiais e burocratas e o baixo grau de participação política por parte da sociedade civil. Além disso, essa mesma tipología não via a necessidade da existência de uma ideologia oficial e de um partido de massa para dar sustentação ao regime (Aquino, 2004: 56). Na outra ponta da doutrina sobre regimes autoritários, O’Donnell vê o Brasil pós-64 como uma nova forma autoritária, denominada por ele de burocrático-autoritária. No seu entender, com essa denominação, procurava distinguir o regime brasileiro - e o argentino - de simplesmente regimes autoritários ou militares ou, ainda, fascistas. Para o autor, o regime burocrático autoritário "corta desde a raiz a ameaça de uma crescente ativação política a cujo compasso foram amolecendo os contrastes do Estado e das classes dominantes sobre o setor popular. O regime burocrático-autoritário impõe uma nova ordem social, mesmo que para atingir tal objetivo, se utilize da violência estatal e paraestatal" (O’Donnell, 1987:53).

Embora alguns autores pretendam caracterizar o Estado Novo de Vargas como um caudilhismo, há evidência, na verdade, de um autoritarismo centralizador e do fortalecimento do Executivo e de suas capacidades técnicas, ou seja, da sua 
racionalidade formal (Cardoso, 1982:48). Com o fortalecimento do Executivo, como no caso do Estado Novo, o Judiciário passa a ser controlado, na prática, por ele; além disso, ocorre a eliminação do Legislativo. A caracterização do Estado Novo no Brasil como um regime fascista, como outros pensam, revela um desconhecimento da principal característica do fascismo, qual seja, de produzir um povo emocionalizado. Ao contrário, o autoritarismo aspira introduzir no seu interior a apatia das massas. Assim, o autoritarismo brasileiro, seja aquele de 1937 a 1945, ou este de 1964 a 1985, dispensa o partido político como ligação organizacional entre a sociedade civil e o Estado, fazendo com que as Forças Armadas suijam como fiadoras da ordem autoritária - como tuteladora ou como dirigente -, sendo que o processo de tomada de decisões políticas preserva uma estrutura hierárquica rígida e centralizada nas mãos do Executivo. Ao Legislativo, quando existente -1964 a 1985 -, reserva-se o papel de ator político coadjuvante ou de membro homologador de decisões superiores (Cardoso, 1982: 44).

As Forças Armadas, faz mister assinalar, exerceram funções diferentes nos dois períodos autoritários: no Estado Novo, os militares tomam o poder para manter Vargas na direção do Estado, porém exercendo o seu papel tutelador do regime. Já no período pós-64, as Forças Armadas assumem a direção do Estado e se organizam nas bases da moderna doutrina militar. Apesar das tentativas, não logrou efeito a institucionalização de uma ideologia própria no autoritarismo brasileiro, onde se projetaria a crença nas virtudes da raça e no destino do povo - o fascismo. Em vez disso, os ideólogos do regime autoritário conseguiram apenas produzir um cimento doutrinário, favorecendo o surgimento de uma mentalidade conservadora, cuja visão de mundo assenta-se no fortalecimento do. aparelho de Estado, no controle social e na expansão económica, limitando o horizonte de expectativas e oportunidades dos atores políticos excluídos do processo.

O surgimento de um Executivo forte, quase ditatorial, levou Boris Fausto, sem cerimónia, a caracterizar o Estado Novo brasileiro como uma ditadura autoritária, ou seja, liberta da parafernália de partidos e eleições (Fausto, 2001 : 22). Da mesma forma, alguns analistas procuram ver uma ditadura militar no regime pós-64 no Brasil, principalmente no período de vigência do Ato Institucional número 5, de 13 de dezembro de 1968.

\section{Cenário 3. O Pensamento Autoritário no Brasil}

Os tenentes de 1930 tomaram-se os generais de 1964. Os tenentes fizeram o movimento militar de 1930, que viria a desembocar no golpe de 1937. Anos mais tarde, já na patente de general, tomaram-se os golpistas de 1964. Os tenentes, legatários da plataforma de Benjamin Constant, que reservava aos militares 
uma participação poderosa na implantação de uma sociedade fraterna, altruística e positiva (Corrêa, 1997:190), tinham no positivismo o ceme do seu movimento -1937 - e na Doutrina de Segurança Nacional -1964 - os elementos necessários para a constituição de uma nova ordem, tempos depois. Assim, muito embora Auguste Comte apresentasse uma doutrina contrária à força militar, Benjamin Constant acreditava que o aparelho militar contribuiria em muito para a implantação do Estado positivo. Na verdade, o positivismo foi a doutrina mobilizadora dos tenentes, com uma visão moderna frente ao patrimonialismo brasileiro. Da mesma forma, um dos componentes presentes nos ideais "revolucionários" de 1964 seria a modernização do país.

Os antecedentes do pensamento autoritário no Brasil foram afirmados claramente nas obras de Azevedo de Amaral, Francisco Campos, Alberto Torres e Oliveira Vianna. Do primeiro autor citado, ao ressaltar as virtudes do autoritarismo, encontra-se a seguinte afirmativa: "O Estado autoritário baseia-se na demarcação nítida entre aquilo que a coletividade social tem o direito de impor ao indivíduo, pela pressão da maquinaria estatal, e o que forma a esfera intangível de prerrogativas inalienáveis de cada ser humano". Na esteira do pensamento de Azevedo Amaral vai-se obter de Oliveira Vianna, no curso do Estado Novo, que o Brasil não precisa de um nacionalismo imperialista dos italianos de Mussolini ou do nacionalismo racista dos alemães de Hitler, mas sim de um presidente da República único, isto é, de um presidente que não divida com ninguém sua autoridade. Em síntese, de um presidente que exerça seu poder em nome da Nação, só a ela subordinado e só dela dependente (Fausto, 2001a: 11). Ressalte-se, ainda, o papel de uma das figuras mais importantes do autoritarismo brasileiro, pois a ele sempre cabia a função de dar forma jurídica e ares de legalidade aos regimes: Francisco Campos.

Há autores que afirmam, até com certa razão, que o golpe de 1964 retomou o fio condutor do pensamento de Oliveira Vianna (Corrêa, 1997: 194). Por outro lado, outros autores encontram na Doutrina de Segurança Nacional a evolução do nacionalismo de Alberto Torres e de Oliveira Vianna (Macedo, 1979: 516). Contudo, dos pensadores modernos, o mais enfático é Wanderley Guilherme dos Santos ( 1998:34), para quem o autoritarismo instrumental - regime militar de 1964 - tem seus antecedentes na década de 1920, justamente nas teses elaboradas por Oliveira Vianna que expressa, pela primeira vez, o dilema do liberalismo no Brasil. Segundo Vianna, o Brasil precisa de um sistema político autoritário, pois só se constrói uma sociedade liberal mediante a adoção de um regime autoritário. Dirá Oliveira Vianna que não existe um sistema político liberal sem uma sociedade liberal. E o Brasil não possui essa tal sociedade mas, ao contrário, uma sociedade parental, clâmica e autoritária (Corrêa, 1997,193). 
Tanto 1937 quanto 1964 representaram a vitória do ideário autoritário. As leituras dos textos de Alberto Torres, Oliveira Vianna e Azevedo de Amaral não deixam dúvidas sobre a formação do pensamento autoritário no Brasil. Torres participou, pós 1930, de revisões constitucionais e coube a ele a elaboração do arcabouço da legislação trabalhista e sindical de Getúlio Vargas. Azevedo de Amaral influenciou boa parte da intelectualidade da época, seja mediante sua participação na direção de vários jornais, seja pela sua produção científica. De todos, o jurista e político Francisco Campos foi o que teve maior atuação política. Deputado Federal e Ministro de Estado da Educação e Saúde - 1930 a 1932 -, reformou o ensino secundário e superior. De 1933 a 1937, exerceu o cargo comissionado de Consultor Geral da República, para, finalmente, se transformar numa das principais peças do autoritarismo do Estado Novo. Participou desde o início das articulações do golpe de 1937, redigiu a Carta Constitucional de 1937 e, na finalidade de Ministro da Justiça, conduziu com mão de ferro a repressão política. Em 1964, atendendo a pedido dos tenentes de 1930 e dos generais de 1964, deu forma jurídica aos primeiros Atos Institucionais (ATs), que implantaram e consolidaram o regime militar.

Para os pensadores autoritários, Torres, Vianna e Campos, principalmente, o Poder Executivo deveria assumir a primazia, opção que se tomou presente com a tomada de poder tout court por Getúlio Vargas em 1937. Nos discursos dos autoritários a ênfase voltou-se para a figura carismática do presidente da República, que passou a personificar o poder. Oliveira Vianna sustenta em muitos de seus textos que o ideal do Estado Novo é ter um chefe de Estado que não seja um chefe de partido, mas uma autoridade que se coloque acima das facções partidárias e grupos de qualquer natureza (Fausto, 2001a: 58-59). No meio dessa discussão, surgia a figura do general Góes Monteiro, figura central do Estado Novo, que defendia como missão especial das Forças Armadas brasileiras a função de poder moderador. A instituição militar deveria assumir a direção política e intervir na vida pública arbitrando a crise instalada na sociedade.

No entender de um dos principais historiadores brasileiros, o pensamento do general aproxima-se do formulado por Oliveira Vianna, Azevedo Amaral e Francisco Campos. As semelhanças, diz ainda Boris Fausto, são notórias: ataque, aliás em linguagem desabusada, ao liberalismo; horror ao federalismo; culto ao papel do Estado; insistência no tema da unidade com o objetivo de construir a Nação brasileira (Fausto, 2001a: 64). Por outro lado, o autoritarismo age de forma repressiva para, no dizer de seus ideólogos, garantir a segurança nacional diante dos inimigos externos e internos. A ameaça subversiva passa a ser o principal motivo, seja em 1937, seja em 1964, para que práticas antidemocráticas dêem sustentação ao regime autoritário. 
Foi justamente esse pensamento autoritário que deu o ingrediente tropical à Doutrina de Segurança Nacional surgida nos anos 40, nos Estados Unidos, e exportada, com rara competência, para os países latino-americanos quando do auge da Guerra Fria e da Revolução Cubana. O golpe de 1964 no Brasil e os demais pronunciamentos militares em toda a América Latina tiveram como pano de fundo a garantia da segurança nacional e o combate ao inimigo extemo - o comunismo - e intemo - a subversão. Em 1930 aparecia nos discursos do general Góes Monteiro a expressão segurança nacional (Trevisan, 1985: 38). $\mathrm{Na}$ verdade, o conceito moderno de segurança nacional só vai aparecer após a segunda grande Guerra, mas nos anos de 1930 havia, no seio do aparelho militar, uma preocupação doutrinária em formar uma mentalidade que sobrepunha a tudo os interesses da Pátria.

No golpe militar de 1964, que vigorou até 1985, a justificação ideológica para a tomada do poder e a modificação de suas estruturas foi encontrada na Doutrina de Segurança Nacional ministrada na Escola Superior de Guerra (ESG), cuja criação, em 1949, com assistência técnica norte-americana e francesa, tinha por objetivo treinar pessoal de alto nível no sentido de exercer funções de direção e planejamento de segurança nacional (Alves, 1984: 24).

O golpe de 1964 não repete o movimento estado novista de 1937 e por isso mesmo não tem as mesmas características de tomada e manutenção do poder. Contudo, 1964 traz consigo todo o pensamento autoritário, formulador doutrinário que foi do golpe de 1937. Tanto isso é real que quando da elaboração do AI 1 - que deu arcabouço institucional ao golpe - o primeiro a ser chamado foi justamente um dos ideólogos do Estado Novo, o jurista e político mineiro Francisco Campos. Durante o Estado Novo, o aparelho militar exerceu o seu papel arbitral-tutelar - que não quer dizer imparcialidade -, isto é, sua ação se restringiu a uma intervenção transitória, de modo a, posteriormente, devolver o poder aos civis e limita-lo, uma vez que ótica castrense entende sua função como restauradora da ordem institucional. Assim, após a intervenção das Forças Armadas na ordem política e a entrega do poder aos civis, seu papel direciona-se para o estabelecimento de limites da ação civil. Em outro momento, em 1964, os militares deixam de ser tuteladores da ação civil para assumirem a função dirigente do Estado (Borges Filho, 2003: 20).

O regime que se instalou em 1964, sustentado por uma aliança civil e militar, e que permaneceu até 1985, seguiu à risca os preceitos da Doutrina de Segurança Nacional. $\mathrm{Na}$ qualidade de força dirigente, as Forças Armadas assumiram a função de partido das elites, manobrando a sociedade civil através da censura, da repressão e do terrorismo estatal, para promover os interesses de uma classe dominante e suas frações de classe, assegurando-lhes condições de supremacia 
em face do social. Como efeito perverso para essa classe dominante, à medida que o aparelho militar fortalecia o Estado e buscava atingir um elevado crescimento económico, as Forças Armadas, como instituição, obtinham um grau elevado de autonomia institucional, sobrepondo-se às classes.

Aquele pensamento jurídico autoritário dos anos de 1930 volta a circular em 1964 e nos anos seguintes, na convicção de que o direito não consiste em normas gerais e permanentes, estabelecidas por um poder juridicamente regulado de maneira a reger as múltiplas situações concretas ou individuais. $\mathrm{O}$ direito seria, então, formado por normas individualizadas e concretas, vis a vis o indivíduo (Borges Filho, 2003: 26). A todo regime fundado sob a égide da Doutrina de Segurança Nacional - Brasil, Chile, Uruguai, Argentina, etc) -, se atribui uma vocação "revolucionária" destinada a modificar o status quo. A nova autoridade se considera autodotada, tendo em vista sua condição "revolucionária", dona de um poder suficiente para eliminar os fatores adversos que perturbam a ordem, e para adotar medidas visando a assegurar e a consolidar o movimento "revolucionário" e impor seus objetivos. Isso quer dizer que o regime autoritário se caracteriza não somente pela usurpação do poder - golpe -, mas também pela concentração em suas mãos de todos os poderes e funções do Estado - a manutenção. Ele supre, evidentemente, uma forma extremamente autoritária do exercício do poder de decisão na esfera estatal. Para que ocorra essa concentração de poder é necessário, portanto, que se instale a violência por parte da polícia política e que se integrem ao aparelho do Estado os meios necessários para a obtenção de informação sobre o "inimigo intemo". Dessa forma, o pensamento autoritário acredita que suas teorias e conceitos sobre o Estado fazem deste um ente dotado de poder discricionário, e sem outros limites que não sua própria automoderação. $\mathrm{Na}$ realidade, o que o pensamento autoritário busca é por aquele Estado absoluto, que aparece como a vontade suprema na arena política. A violência, estatal a paraestatal, é o meio que o Estado absoluto se utiliza para atingir seus fins.

\section{Cenário 4. Principiando Eventos e Demarcando os Fatos}

Há um sentimento costumeiro entre os intelectuais brasileiros de que o ano de 1930 representou o marco de inflexão da história brasileira, propiciando uma modalidade de mudança social que se espraiou pela política, pela economia e pela cultura, lançando o Brasil na modernidade capitalista. O processo político e social, entretanto, foi conduzido em um arranjo institucional autoritário, mediante um Estado que organiza a Nação e, acima da sociedade, dirige a mudança, ensejando a construção de identidades coletivas a partir da comunidade e a 
realização do bem comum, sobrepondo-se a qualquer forma de particularismo de classes, de estamentos, de identidades locais ou de partidos. Para isso, este Estado, acima da sociedade, conduz com mão de ferro a mudança, esvaecendo qualquer forma de conflito social por meio do uso da violência, mesmo que esta careça de legitimidade, tendo em vista o fato de a inflexão produzida por 1930 significar a transição de uma ordenação oligárquica e liberal para uma ordenação capitalista e autoritária. Ou seja, a violência teria sido necessária, justificada e institucionalizada pelo Estado, uma vez que o contexto político e social carecia de uma institucionalização eficiente da ordem, capaz de arrefecer, por meios legítimos, os conflitos sociais e dar legitimidade à mudança.

O presente texto está destinado a pensar o modo de acordo com o qual o Estado, durante o período do Estado Novo e durante o Estado autoritário criado em 1964, utilizou os meios de violência para ordenar a sociedade, afirmando identidades que seriam constituídas a partir da Nação, sobretudo o uso da violência para coibir formas de oposição à ordem, construídas por movimentos sociais que pleiteavam formas revolucionárias de mudança social, por fora das instituições do regime. Todavia, é necessário um passo atrás para principiar os eventos e demarcar os passos seguintes que informarão este ensaio.

Cumpre destacar ainda que o uso da violência pelo Estado autoritário brasileiro ocorreu através de duas modalidades: (a) a violência física, utilizando meios de repressão à oposição ao regime, tais como a tortura e, (b) a violência simbólica, que através da manipulação de símbolos, constrói uma forma de identificação com o regime autoritário, atuando através da censura aos meios de comunicação e do controle da informação.

A inflexão política produzida em 1930 é fruto de forças sociais que minaram a legitimidade da República Velha, conjugando os interesses de diferentes grupos que se diferenciaram funcionalmente, dando a característica de uma transição institucional cujo dilema é produzir formas de inclusão destes grupos, os quais forçaram seu reconhecimento no âmbito do direito. O início do século XX representa, desse modo, a diferenciação funcional da sociedade brasileira, emergindo à cena política uma sociedade marcada por classes urbanas em contraposição a um arranjo institucional sustentado por uma oligarquia rural. A revolução de 1930, nesse sentido, não tem o caráter de uma ruptura da ordem, mas o rearranjo das instituições políticas em função das diferentes classes sociais emergentes, que tinham a aspiração de participar politicamente sem os vícios eleitorais da República Velha (Soares, 1973:36). Porém, as classes não contavam com um centro de irradiação de ideologias, uma vez que a esfera pública do regime republicano era descentralizada no âmbito dos estados da federação e dos municípios, tendo em vista identidades regionais que organizavam a sociedade e a política. 
Este processo, por sua vez, impediu que se constituísse no Brasil uma classe que pudesse se revelar como arauto da modernidade. De outro lado, a emergência de um processo de industrialização do país modificou e acelerou as mudanças sociais em curso, resultando na presença de interesses ligados a uma burguesia industrial em ascensão e o surgimento de contradições de classe com a organização dos trabalhadores em sindicatos. Este processo, desse modo, criou um fosso entre o papel das classes na mudança social e a irradiação de ideologias, provocando o surgimento de um cenário político e social desprovido de hegemonia.

Sustentada por um compromisso oligárquico (Lima Sobrinho, 1975), a política brasileira da República Velha organizava-se pela forte presença de elites regionais, tendo em vista um sistema federativo que garantia a fragmentação do poder e a autonomia dos estados em relação ao poder central. Como resultado deste arranjo institucional, a dominação é exercida por uma oligarquia que se revezava no poder, tendo em vista um sistema de compromisso informal e assegurado pelo largo uso da corrupção eleitoral, do nepotismo e do empreguismo (Leal, 1997). O compromisso oligárquico é expressão de uma conjugação do tradicional e do moderno, uma vez que possibilitou a modernização via autonomia dos estados como São Paulo e Minas Gerais, que seriam dotados de uma economia em expansão, sem romper com o tradicional, uma vez que as elites regionais seriam responsáveis por dar vida institucional e por vincular a sociedade ao sistema político (Lessa, 2001:21). A vida institucional republicana, portanto, evitava o fortalecimento de instituições representativas de interesses de classes, ao mesmo tempo em que fragmentava a comunidade política nacional, criando várias ordens regionais dotadas das mais variadas vocações económicas e sociais. Como pano de fundo, a vida institucional republicana apoiou-se na autonomia de um mercado que garantiria a autonomia dos grupos oligárquicos, ao mesmo tempo em que a autonomia de uma burguesia industrial em ascensão, no centro da economia brasileira (Schwartzman, 1982).

O marco de 1930, desse modo, foi a degradação da política oligárquica, uma vez que o sistema de compromisso foi incapaz de incorporar os novos grupos emergentes à cena social. A ascensão da classe média como ator que pleiteava sua participação no processo político (Ramos, 1963), os militares herdeiros do Tenentismo de 1922 (Fausto, 2001b), a burguesia industrial e o ideário do desenvolvimento económico (Sodré, 1962) possibilitaram a propulsão da crise institucional da República Velha, ensejando a quebra do compromisso oligárquico e a inclusão de novos atores à cena política. Como resultado desse processo de crise institucional, estourou a Revolução em Minas Gerais e no Rio Grande do Sul, a 3 de outubro de 1930, espraiando-se pelo Nordeste. O substancial da Revolução de 1930 é que sua base social foi marcada pela complexa heterogeneidade, 
não cabendo a nenhuma classe social o papel de representante dos ideários revolucionários ou tutora de uma hegemonia capaz de modificar as bases sociais. A classe média era por demais heterogénea, sendo composta de profissionais liberais e funcionários públicos ligados à Aliança Liberal, que, num primeiro momento, encontraram forte oposição da igreja. Quanto à burguesia industrial, o regime federativo da República Velha deixou profundas marcas regionais nos diferentes setores, estando eles representados pelos partidos estaduais, tomando-os pouco afeitos à oposição do regime, além do fato de as diferenças regionais no plano económico não ter possibilitado a criação de um consenso em tomo da industrialização. De outro lado, o rompimento do compromisso oligárquico fragmentou as oligarquias, derivando um processo de diferenciação entre novos e velhos oligarcas, sendo os últimos o alvo preferencial do levante militar. Finalmente, os militares emergiram como atores políticos a partir do Tenentismo, encontrando oposição nas tropas fiéis ao regime, uma vez que o poder de polícia, durante a República Velha, encontrava-se nas mãos dos estados (Fausto, 2001b:325).

Tendo em vista esta heterogeneidade das bases sociais da Revolução de 1930, nenhuma classe ou grupo social qualquer pode ser considerada como classe hegemónica. Os interesses e a formação social eram por demais variados para que pudessem comungar com a criação de um novo horizonte político e ideológico. Ao mesmo tempo em que o novo regime atendia aos anseios da burguesia industrial em ascensão, promoveu um rearranjo das instituições políticas, fazendo permanecer o domínio oligárquico, apesar da inclusão da classe média e dos militares herdeiros de 1922. O dilema passava a ser como construir uma institucionalização política eficaz, capaz de agregar os diferentes estratos da sociedade brasileira e assegurar um mecanismo de pacificação social eficiente, que desse termo aos conflitos políticos e sociais.

Os anos seguintes a 1930 representam avanços e descontinuidades no plano institucional do Estado. Devido à fragmentação do poder e aos interesses emergentes por parte de grupos até então subalternos, assiste-se a uma escalada do autoritarismo como solução para o conflito. Uma vez heterogénea, a base social sobre a qual se assentou mais tarde o Estado Novo e o Regime Militar precisa ser controlada por um poder centralizador, capaz de assegurar a existência de uma ordem através de mecanismos de violência.

\section{Cenário 5. A Ampliação dos Meios de Violência e o Estado Novo}

Subindo ao poder em 1930, Getúlio Vargas executou medidas centralizadoras, dissolvendo os legislativos em âmbito federal, estadual e municipal, além de nomear interventores nos governos estaduais, estabelecendo, através do Código 
dos Interventores de 1931, as normas para a subordinação dos estados ao poder central. Ademais, as medidas de Vargas limitaram a área de atuação dos estados no plano económico, ficando os mesmos proibidos de contrair empréstimos sem a permissão do governo federal. As medidas centralizadoras, entretanto, encontraram forte oposição por parte dos setores mais modernos da política brasileira, resultando no levante militar de 1932 em São Paulo, visando à constitucionalização do país, à convocação de eleições gerais e ao controle sobre as forças militares tenentistas. A marca do regionalismo ainda fazia-se presente no novo contexto institucional, estourando em São Paulo a revolução contra o governo federal, cuja conseqüência foi a reabertura do Congresso e a (re) constitucionalização do país a partir de 1934.

Os anos seguintes a 1930 mostraram seguidas crises institucionais, uma vez que o plano político e legal não encontrava guarida no plano ideológico das classes, ainda marcadas por forte fragmentação das identidades e dos interesses. No plano político e simbólico, o Estado nacional necessitava colocar-se acima das classes e do regionalismo que perpassaram o levante de 1930, organizando a Nação e tutelando as forças sociais presentes ou não na arena política (Wemeck Vianna, 2001:130). Com o apoio dos liberais, em 1935, o governo federal aprovou, junto ao Congresso, a primeira Lei de Segurança Nacional, provocando manifestações nos sindicatos e no Clube Militar, que representava o oficialato do Exército e da Marinha. A Lei de Segurança Nacional definiu os crimes contra a ordem política e social, visando ao controle da propaganda subversiva organizada por qualquer associação ou partido que tivesse o objetivo de subverter a ordem autoritária em construção. Diante da heterogeneidade das classes, fazia-se importar um plano ideológico autoritário, apostando no Estado como o grande arauto de uma ordem institucional voltada para o desenvolvimento e para a modernização. No plano ideológico, caberia ao Estado arregimentar as classes, culminando no fortalecimento das instituições militares e no uso indiscriminado da violência, tendo em vista a Lei de Segurança Nacional.

Diante da oposição de setores da sociedade ligados aos comunistas e aos tenentes de esquerda, em 1935, paralelo ao surgimento da Lei de Segurança Nacional, veio a público a Aliança Nacional Libertadora, que, sob a liderança de Luís Carlos Prestes, defendia um conteúdo nacionalista, a suspensão do pagamento da dívida extema, a nacionalização das empresas estrangeiras, a reforma agrária e a constituição de um governo popular, que garantisse as liberdades civis. Sob influência da Internacional Comunista, a Aliança Nacional Libertadora reuniu diferentes setores das classes, inclusive das forças militares, colocando-se como oposição ao autoritarismo de Vargas, planejando, em novembro de 1935, um levante militar que possibilitasse a tomada do poder. 
O resultado foi a repressão violenta por parte das forças legais, levando ao confronto com as tropas insurgentes em Natal, no Recife e no Rio de Janeiro, culminando na prisão de suas lideranças e em centenas de mortos. A derrota do levante da Aliança Nacional Libertadora contra a ordem vigente possibilitou a constituição de uma justificativa ideológica para o uso da violência, uma vez que a repressão era contra a escalada comunista no plano internacional. Ou seja, o fracasso da ANL possibilitou a identificação do inimigo externo - o comunismo - e do inimigo interno - os grupos subversivos -, demandando a organização da unidade mediante a afirmação, inclusive no plano jurídico, dos valores da comunidade através da Nação.

Durante o ano de 1936, o Congresso aprovou todas as medidas solicitadas pelo Executivo, tendo em vista a justificativa de ameaça da ordem, decretando o estado de sítio por sessenta dias e assegurando ao governo o uso extensivo da força contra as tropas rebeldes. O Estado criou, em 1936, órgãos específicos para a repressão, formando a Comissão Nacional de Repressão ao Comunismo e o Tribunal de Segurança Nacional. Ademais, Vargas deu à polícia da capital federal maior poder para reprimir atividades comunistas ou que estivessem contra a ordem vigente, tal como a prisão de Olga Benário e a sua posterior extradição para a Alemanha Nazista.

Tendo em vista a institucionalização dos meios de violência física em 1936 e a justificativa ideológica de repressão ao comunismo, o cerco militar ao Congresso em 1937 e a elaboração de uma nova Carta Constitucional por Francisco Campos deram ensejo ao Estado Novo que, ao melhor estilo autoritário, surgiu de um golpe sem grandes mobilizações, tendo em vista a derrota dos comunistas e dos movimentos populares. A centralização proporcionada pelo Estado Novo modificou os mecanismos de representação das classes junto ao Estado, retirando do Congresso e dos partidos políticos o papel de agregar os interesses mediante representação. Caberia ao Estado criar a síntese dos interesses através de instituições corporativas, mediando a aliança entre a classe média alojada na burocracia civil, a burguesia industrial e as forças militares, promovendo a industrialização do país sem grandes abalos, ou seja, dentro da ordem.

No plano concreto, portanto, mediante a institucionalização dos meios de violência, o Estado poderia se colocar acima das classes, tutelando os interesses através de formas de coerção, uma vez que as liberdades civis estavam suspensas, já que a Constituição de 1937 decretava o estado de emergência. A implantação do Estado Novo concretizou as perspectivas de centralização política oriundas de 1930, dando uma carnadura institucional capaz de assegurar a ordem sem nenhuma ruptura radical com as práticas e instituições gestadas desde então, 
conformando os interesses ligados aos planos de industrialização sem romper com o domínio agrário das oligarquias regionais.

Restava, por outro lado, construir mecanismos de identificação das camadas populares com o regime, combinando formas de coerção dadas pela violência institucional com formas consensuais oferecidas por uma violência simbólica. Com efeito, o Estado Novo buscou formar uma opinião pública favorável à nova ordem, manipulando símbolos e discursos sedutores em tomo do tema do trabalho' ${ }^{1}$, além de medidas repressoras sobre a imprensa, censurando os meios de comunicação e reformando a política educacional.

No que tange à manipulação de símbolos para a criação de uma identidade nacional, sobreposta às identidades regionais, o Estado Novo criou, em 1939, o Departamento de Imprensa e Propaganda (DIP), que atuou como censor das áreas de comunicação e cultura, controlando e conformando ideologicamente as massas urbanas, porém, sem mobilizá-las. O departamento fazia o controle da publicação de informações, proibindo publicações estrangeiras que ferissem o orgulho da Nação, bem como obras de arte, filmes, programas e literatura social e política que contrariassem os princípios da nova ordem.

Como prática, a violência simbólica, assim como a violência física, ganhou formas institucionais no interior do regime autoritário do Estado Novo, fazendo os setores populares comungarem com a engenharia institucional construída a partir de 1937. Diante da violência física, que conformava o indivíduo exteriormente, e diante da violência simbólica, que o conformava internamente, o Estado Novo se sobrepôs às classes enquanto aparelho ideológico dos setores que conquistaram a dominação, especialmente a classe média, as oligarquias rurais, a burguesia industrial emergente e as forças militares, sendo esses últimos os fiadores do processo. Mediante um novo compromisso institucional configurado na aliança destes quatro setores da sociedade (Fausto, 2001b: 368) e a ausência de uma classe hegemónica, o Estado Novo pôde perseguir, prender e torturar intelectuais e políticos ligados a setores de esquerda.

O Estado Novo realizou os objetivos da Revolução de 1930 e do pensamento autoritário, promovendo a integração nacional por meio de violência discriminada contra setores da sociedade que se opunham ao regime, propiciando a entrada ${ }^{1}$

\footnotetext{
Importante destacar que o Estado Novo ensejou uma política trabalhista que incluiu, na forma de direitos, os trabalhadores industriais mediante representação funcional dada pelos sindicatos. Enquanto forma de movimento social, a representação funcional dos sindicatos apenas poderia ocorrer uma vez que eles fossem legalizados, ou seja, incluídos na ordem autoritária através da Consolidação das Leis Trabalhistas (CLT). Ademais, a política trabalhista de Vargas excluiu o campesinato da ordem, visando a não romper com o domínio oligárquico sobre a terra e as formas de trabalho no campo. A esse respeito, conferir Wemeck Vianna (1999).
} 
do Brasil na modernidade capitalista através de larga industrialização conduzida sob tutela do serviço público. O Estado Novo propiciou, desse modo, uma modernização conservadora do Brasil, fomentando a industrialização sem o rompimento dos modelos de dominação existentes na sociedade, a partir da grande propriedade da terra (Wemeck Vianna, 1999:175).

Todavia, o regime foi se distendendo, surgindo em seu interior forças favoráveis à democratização, uma vez que o aparelhamento institucional foi se afastando, gradativamente, de uma das forças centrais que lhe dava sustentação: os militares, que tiveram uma atuação dúbia, uma vez que o Brasil entrou na Segunda Guerra Mundial para combater forças repressoras ligadas a uma ideologia fascista ou nazista. $O$ peso desta atuação dúbia sobre a instituição militar propiciou um contexto que levou à posterior democratização, uma vez que um dos princípios fundamentais é a manutenção da coesão intema e da hierarquia no interior da instituição militar.

Em fevereiro de 1945, Getúlio Vargas baixou o Ato Adicional à Carta de 1937, convocando eleições gerais e decretando o novo Código Eleitoral, possibilitando a conformação de novos partidos políticos e a emergência da democracia. No interregno dos anos de 1945 e de 1964, o Brasil assistira a um declínio provisório dos mecanismos institucionais de violência física e simbólica em nome da (re) democratização. Todavia, este período foi marcado pela instabilidade institucional e pela dissolução do compromisso firmado entre as classes durante o Estado Novo. O acirramento do conflito resultou em nova decadência institucional, convocando os militares à arena política, para que reconstruíssem os instrumentos de violência política, visando a (re) estabelecer a ordem.

\section{Cenário 6. A Reconstrução dos Meios de Violência no Estado Autoritário de 1964}

A nova ordem institucional do Estado brasileiro, iniciada em 1945, resgatou as liberdades civis, revogando o estado de emergência decretado em 1937. Ademais, resgatou um modelo político sustentado em partidos, iniciando, a partir da vitória de Dutra, uma nova constitucionalização do país. A Constituição de 1946 optou por um modelo liberal-democrático, apesar de manter em muitos pontos a representação funcional derivada do modelo corporativo. A organização partidária estava definida, basicamente, na presença de três partidos: o Partido Trabalhista Brasileiro (PTB), que seria responsável por aquiescer a classe operária, mediante representação das organizações sindicais; a União Democrática Nacional (UDN), que representava a ala mais conservadora, os militares nacionalistas e parte razoável da burguesia industrial; e finalmente, o Partido Social Democrático 
(PSD), que representava a velha oligarquia agrária e setores de uma burguesia agro-exportadora.

O interregno democrático iniciado em 1945 procurava dar representação institucional às diferentes classes da sociedade brasileira, à exceção do campesinato, tendo em vista o horizonte da modernização conservadora e a suspensão dos mecanismos de violência física e simbólica, fomentando uma legalidade que assegurasse uma ordem pacífica. Entretanto, os mecanismos institucionais criados pela Constituição de 1946 não foram suficientes para controlar o conflito entre as classes, que aspiravam a tomar o poder e a controlar a ordem em vista de uma legalidade que carecia de estabilidade. O interregno democrático iniciado em 1945 representa, na história brasileira, um período de grande instabilidade política, uma vez que a organização das classes em partidos serviu para fermentar ainda mais os debates nos planos ideológico e económico, esvaecendo as formas fracamente consensuais construídas a partir de 1937.

O Estado democrático de 1946 assistiu a uma sucessão de tentativas de golpe por parte dos militares do Clube Militar e da Escola Superior de Guerra, sendo o principal deles o golpe contra a eleição de Juscelino Kubitscheck em 1954. Enquanto setores das Forças Armadas - Aeronáutica e Marinha - denunciavam a eleição de Kubitscheck como uma "mentira democrática"2, o ministro da Guerra, general Lott, mobilizou tropas do Exército no Rio de Janeiro, ocupando prédios públicos e estações de rádio e jornais, assegurando, dessa forma, a posse do presidente eleito. O "golpe preventivo" pretendia ser uma intervenção militar que impedisse a politização das Forças Armadas e garantisse a continuidade da ordem institucional, sem fomentar o conflito partidário que já se acirrava entre as forças políticas representadas, essencialmente, pelo PTB e pela UDN (Guimarães, 2001: 169).

A continuidade do governo Kubitscheck apenas foi possível com o relativo sucesso do Programa de Metas, que fomentou o desenvolvimento económico e a industrialização do país, arrefecendo ou suspendendo, temporariamente, o conflito entre as classes. No plano partidário, a aliança entre PSD e PTB garantiu maioria no Congresso e importante entrada do governo na burocracia civil e nos sindicatos, limitando, desse modo, as greves e o potencial de conflito. De outro lado, o sucesso do "golpe preventivo" possibilitou que os militares apoiassem a continuidade da ordem democrática. Restavam apenas como oposição os setores mais conservadores da classe média, representada pela UDN, sob a liderança

2 Termo referente ao discurso fúnebre proclamado pelo Coronel Bizarria Mamede, em ocasião da morte do presidente do Clube Militar, general Canrobert Pereira da Costa (Fausto, 2001b: 421 ). 
de Carlos Lacerda. O sucesso do Programa de Metas, no plano económico, entretanto, relativamente silenciou a oposição da UDN.

A sucessão do presidente Kubitscheck foi marcada pela emergência de pequenos partidos à arena política, como o PTN e o PSP, cristalizando formas populistas e conservadoras, as quais defendiam a moralização dos costumes políticos e denunciavam a corrupção em relação ao grupo getulista do PTB, referendando o discurso da UDN de Carlos Lacerda. Com a vitória de Jânio Quadros, pelo PTN, com 48\% dos votos, e João Goulart para vice-presidente, tendo em vista uma dissidência sindical no PTB, nascida em São Paulo, o novo governo carecia de uma maioria no Congresso, além de contar com um contexto económico mais difícil, uma vez que a carestia se ampliava em virtude da recessão económica. Sem uma base política de apoio, o desastroso governo Jânio Quadros encontrou forte oposição do PSD e do PTB, que tinham maioria no Congresso, além de Carlos Lacerda ter passado para a oposição, uma vez que o presidente agia de modo independente da liderança udenista. Na tentativa de somar maior poder, Jânio renunciou à presidência da República, resultando em um desastre político sem precedentes ${ }^{3} .0$ dilema passa a ser a sucessão de Jânio, uma vez que João Goulart visitava a China comunista, propiciando o protesto da UDN e o descontentamento dos setores mais conservadores da sociedade brasileira, da Igreja e das Forças Armadas. A continuidade do regime apenas foi possível com uma solução de compromisso entre as forças partidárias no Congresso, fazendo com que o Brasil passasse de uma organização presidencialista para parlamentarista, reduzindo os poderes do novo presidente da República: João Goulart.

No contexto de uma efervescência nas bases da sociedade brasileira e dos partidos, no plano intemo, e do combate ao comunismo, no plano internacional, o governo João Goulart enfrentou fortes mobilizações e pressões sociais, advindas dos setores conservadores e dos novos movimentos sociais que entraram na arena política: as Ligas Camponesas, o movimento estudantil e a Igreja, mediante uma participação ativa no processo político (Fausto, 2001b: 447). Nesse contexto, o governo Goulart tentou aprovar as reformas de base, dando primazia ao movimento operário através da representação consolidada no PTB. O objetivo era mudar dispositivos constitucionais essenciais, propiciando a reforma agrária através da desapropriação de propriedade da terra, a reforma urbana, criando condições para que o inquilinato se tomasse proprietário, e a extensão de direitos políticos a setores até então marginalizados: os analfabetos e os inferiores das forças militares. Como chama a atenção Boris Fausto, o primeiro

\footnotetext{
Até hoje, não há consenso entre os historiadores sobre o episódio da renúncia de Jânio, uma vez que não há fontes histórias coesas que atestem o fato.
} 
ponto das reformas de base do governo João Goulart serviu para romper o estado de compromisso que sustentava o modelo de modernização conservadora no Brasil, uma vez que incluía o campesinato e batia de frente com os interesses da burguesia agrária e da oligarquia rural (Fausto, 2001b:444).

As reformas de base e o poder do movimento operário serviram para fermentar o conflito entre as classes e os partidos, uma vez que ganharam ímpeto as invasões de terra e a sindicalização rural por parte das Ligas Camponesas. No plano partidário, Goulart encontrava oposição dentro do PTB, que reclamava de suas vacilações nas reformas sociais, além da forte oposição por parte da UDN, que reforçava um discurso conservador. No contexto de forte instabilidade política, acirrada pelo confronto entre os partidos no âmbito do Congresso e do Governo, a resolução de conflitos pela via democrática cada vez mais passou a se arrefecer, tomando-se desprezível por parte dos atores políticos. A solução cada vez mais passou a ser encontrada em mecanismos de violência, como o episódio da ameaça de Leonel Brizóla em relação ao potencial cerco militar à região Sul do Brasil, organizando um esquema militar de resistência, além de mobilizações populares em Porto Alegre. Entre as Forças Armadas, cresciam os movimentos de conspiração contra João Goulart, propiciando uma "intervenção defensiva" contra os excessos governamentais, especialmente sua ligação com a Internacional Comunista e as reformas de base.

A crise de 1964, antes de qualquer coisa, é uma crise política e institucional do regime democrático inaugurado em 1945. O acirramento do conflito entre os partidos políticos, representantes das classes sociais, e o esvanecimento dos mecanismos democráticos de resolução de conflitos promoveram um contexto de desordem latente, rompendo com o compromisso instaurado em 1945 pelas elites políticas (Santos, 1986:97). A desordem inaugurada pelas invasões no campo, e a desordem nos setores conservadores e operários do mundo urbano, promoveram um contexto social em que não seria possível a estabilidade por via democrática. O ímpeto autoritário aflorava nos diferentes setores da sociedade, inclusive entre os setores operários do PTB, que, através do Governo João Goulart, adotaram um caminho que passava por medidas excepcionais, como o estado de sítio decretado em 1963, mas que fracassaram no âmbito do Congresso, porque era mal visto tanto pela direita, quanto pela esquerda radical (Fausto, 2001b: 458).

$\mathrm{O}$ acirramento do conflito entre as classes sociais e os partidos criou um contexto em que a via autoritária seria a única capaz de promover a ordem social, cabendo às Forças Armadas liderarem esse processo em vista dos princípios da paz social, do respeito à hierarquia e do controle ao comunismo. Em 31 de março de 1964, foi desferido o golpe derradeiro na legalidade democrática, vindo a público o golpe de Estado patrocinado pela elite militar e pela elite 
conservadora, mobilizando tropas sediadas em Juiz de Fora, Minas Gerais, para tomar as mas do Rio de Janeiro, ainda capital da República. A manutenção da democracia não encontrou nenhum esforço de preservação por parte das elites, polarizando posições entre os partidos, fazendo-se necessária a sobreposição de um estado de exceção que reordenasse a sociedade, através da contraposição da violência a qualquer ilusão ligada ao comunismo ou à esquerda.

Com o comando militar assumindo o poder, com o ideal de livrar o Brasil da corrupção e do comunismo, o novo regime começou a modificar as instituições do país através de decreto, fomentando mecanismos de violência com a justificativa de instaurar a ordem social. É através dos Atos Institucionais (AI), justificados pelo fato de um golpe de Estado ser um fato criador de direito, que os militares organizaram a repressão a movimentos de esquerda, especialmente contra as Ligas Camponesas, contra o movimento estudantil e contra o movimento sindical. O Ato Institucional número 1 não revogou a Constituição de 1946, mantendo seus institutos jurídicos com mudanças substanciais e a continuidade do funcionamento do Congresso Nacional. Além disso, o AI1 convocou eleições indiretas no Congresso Nacional, saindo vitorioso, então, o presidente Humberto Castelo Branco, general de alto prestígio dentro da corporação.

O Ato Institucional número 1 organizou o uso da violência no Brasil sob o regime autoritário, cassando mandatos nos diferentes níveis da federação, além de instalar os Inquéritos Policial-Militares (IPM's), que imputavam responsabilidade criminal contra os sujeitos que praticavam crimes contra o Estado, contra o património e contra a ordem social e política. As Forças Armadas, desse modo, ganharam poderes excepcionais, desencadeando perseguições contra todos os inimigos do regime, institucionalizando a prática de tortura e de prisão indiscriminada. Em um primeiro momento, os principais inimigos foram as Ligas Camponesas, que sofreram forte repressão no campo, além das intervenções praticadas pelas Forças Armadas em sindicatos e federações de trabalhadores. Além do IPM, o AI 1 criou o Serviço Nacional de Informações (SNI), órgão que seria responsável pelo controle da informação, no plano da violência simbólica - instaurando o medo como mecanismo legitimador do regime - e pela coleta de informação a respeito das organizações de esquerda criminosas, que atentavam contra a ordem e a segurança nacional.

$\mathrm{O}$ AI 1 deu poderes excepcionais às Forças Armadas, mas teria um prazo de validade, limitando sua vigência até janeiro de 1966, quando, em tese, as forças militares devolveriam o poder aos civis. Porém, expirada a vigência do AI1, por uma manobra política dos setores mais conservadores da instituição militar, o presidente Castelo Branco decretou o AI2 em outubro de 1965, que reforçou os poderes do presidente, que passaria a poder baixar atos adicionais aos atos 
institucionais. A principal novidade do AI2 era a indeterminação do conceito de segurança nacional, propiciando uma ampliação indiscriminada de sua prática, e a extinção dos partidos políticos existentes, criando um sistema bipartidário artificial, dividido entre a Aliança Renovadora Nacional (Arena) e o Movimento Democrático Brasileiro (MDB). O governo Castelo Branco promoveu amplas alterações no plano institucional do Estado, fazendo aprovar, mediante o AI4, em 1967, uma nova Constituição, ampliando os poderes conferidos ao Executivo em assuntos de segurança nacional, institucionalizados mediante o AI2.

No mesmo ano de 1967, passado o primeiro impacto da repressão, a oposição, articulada pelos movimentos de esquerda, voltou a se organizar. As modificações promovidas no âmbito institucional pelo regime autoritário não foram suficientes para criar uma ordem social pacífica. Iniciaram-se novas mobilizações contra a ordem instaurada pelos militares com as greves de Contagem e de Osasco, além de mobilização do movimento estudantil. De outro lado, grupos radicais fomentaram a luta armada, especialmente a Aliança de Libertação Nacional (ALN), liderada por Carlos Marighella, o Movimento Revolucionário 8 de Outubro (MR-8) e a Vanguarda Popular Revolucionária (VPR), ligada a militares de esquerda, insatisfeitos com o regime, entre eles, Carlos Lamarca.

A escalada da luta armada por parte de movimentos revolucionários e a expiração do AI 1, que obrigaria os militares a devolverem o poder aos civis, proporcionou que grupos mais conservadores dentro da instituição militar realizassem uma revolução dentro da revolução, instituindo o AI5. O Ato Institucional número 5 fechou o Congresso Nacional, deu poderes para que o Executivo interviesse nos estados e nos municípios, cassou mandatos e suspendeu os direitos políticos e as liberdades civis. Ademais, pelo AI5, ficou suspenso o habeas corpus aos acusados de crime contra a segurança nacional e infrações contra a ordem económica e social. A partir do AI5, o comando militar pôde organizar os órgãos de vigilância e de repressão a partir do SNI, do Departamento de Operações e Informações (DOI) e do Centro de Operações de Defesa Interna (CODI). As instituições responsáveis pela repressão institucionalizada, tendo em vista o problema da segurança nacional, responderam às pressões e às revoltas praticadas pelos setores da esquerda radical, criando medidas formais de violência física, fazendo com que a tortura se tomasse uma prática costumeira nos porões das Forças Armadas. De outro lado, foram criadas medidas formais de violência simbólica, censurando os meios de comunicação e criando uma propaganda oficial do regime, atrelada a uma comunidade de informações que organiza a Nação pelo alto.

A característica central das práticas de violência por parte do Estado autoritário brasileiro foi a multiplicação de institutos jurídicos formais, que legalizariam a violência como um meio legítimo de garantir a segurança nacional. Primeiro, 
pelo AI 13, cria-se a pena de banimento do território nacional, expulsando do Brasil aqueles agentes perturbadores da ordem e que não se identificavam com a Nação. O AI 13 foi um importante mecanismo de violência simbólica por parte do Estado autoritário, uma vez que confere ao medo um dos fatores essenciais para a sua legitimação diante de seu papel de criar, artificialmente, a Nação. De outro lado, o AI 14 instituiu a pena de morte, que, do ponto de vista formal, nunca foi aplicada, mas serviu para inocentar militares no âmbito dos Tribunais Militares, justificando as execuções sumárias e as torturas, as quais eram apresentadas como tentativas de movimentos radicais de romper a segurança nacional (Fausto, 2001b: 481).

No plano da violência simbólica, o Estado autoritário, além do AI 13, que combinava as duas modalidades de violência, deu forte importância à propaganda, criando a Assessoria Especial de Relações Públicas (AERP), responsável pela propaganda do regime. De outro lado, ao SNI, durante do governo Médici, coube o papel de controlar os programas realizados pelos veículos de comunicação. A combinação de controle e propaganda, em um modelo muito semelhante ao do DIP, durante o governo Vargas, acompanhado de um grande êxito na área económica, serviu para reforçar um espírito nacionalista, dando uma característica comunitária ao regime, tomando-o, por essa via, legítimo e com o poder político de excluir todo aquele que se colocasse contra a Nação.

A tortura foi o mecanismo a partir do qual a repressão desmantelou as organizações da luta armada de esquerda, cultivando a violência como forma de controlar os conflitos no âmbito da sociedade, fazendo com que o regime do Estado autoritário se fizesse reproduzir mediante a combinação de propaganda e medo, contando ainda com o sucesso momentâneo do "milagre brasileiro" no plano da economia. Em essência, a prática de tortura nunca foi oficializada pelo regime, mas ganhava formas institucionais quando mecanismos jurídicos foram criados pelos Atos Institucionais para justificar sua prática. Por outro lado, a repressão fomentou a luta armada dos movimentos de esquerda, que passaram a acreditar na reforma do regime e no fim da repressão apenas, também, com o uso da violência. Pelo menos até 1971, a luta armada conseguiu criar focos de resistência à repressão utilizando-se de seqüestros de autoridades e ações espetaculares de assaltos a bancos, para financiarem-se. A exceção é a guerrilha do Araguaia, organizada pelo Partido Comunista do Brasil - PC do B, o qual vivia na ilegalidade -, que criou um foco de resistência bastante eficaz. Apenas em 1975 os militares puderam reprimir eficazmente a guerrilha, transformando a área do Bico do Papagaio, no Pará, em zona de segurança nacional.

A legitimação do Estado autoritário brasileiro, durante o regime militar, estava assentada no tripé propaganda, medo e êxito económico. Todavia, a partir de 1974, 
iniciou-se a distenção dos mecanismos de violência. O fracasso do "milagre brasileiro", acompanhado da emergência de novos movimentos sociais, impediu que dois dos tripés do Estado autoritário brasileiro do regime militar se concretizassem. Por não haver uma correspondência do regime com dominação de classe (Fausto, 2001b: 513), uma vez que o regime colocava-se acima das classes, o fracasso do "milagre" propiciou a reestruturação da oposição oficial ao regime no âmbito do MDB e no âmbito de instituições representativas da sociedade civil, como a Ordem dos Advogados Brasileiros (OAB) e a Igreja, introduzindo uma propaganda de oposição a par da propaganda oficial. Sustentado apenas no medo fomentado pela tortura, o regime militar não tardaria a dissolver-se, ensejando uma transição para a democracia, porém controlada pela própria instituição militar (O’Donnell, 1986:123).

O fato é que a prática de tortura poderia afetar não o Estado, mas a instituição militar, uma vez que ela era de responsabilidade de oficiais de baixa patente, que deixavam de respeitar a hierarquia, tendo em vista o fato de a tortura ser uma prática ocorrida em segredo. De outro lado, havia uma luta de bastidores entre a ala nacionalista e a linha dura do regime militar. Os efeitos da tortura, além daqueles sofridos por parte dos opositores ao regime, recaíram sobre a instituição militar, que, para restaurar a hierarquia, fez necessário o abrandamento dos mecanismos de repressão pela violência física e simbólica. A partir do governo Geisel, iniciou-se um processo de liberalização do regime político, criando uma transição "lenta, gradual e contínua" para a devolução do poder aos civis. Geisel iniciou o processo de abertura, apesar de ainda restar a oposição sistemática realizada pela linha dura, que utilizou a violência para permanecer no poder, como atestam bs seqüestros de autoridades políticas, a bomba contra o escritório da OAB em São Paulo e a bomba no Riocentro, no Rio de Janeiro.

Apesar dos percalços, a transição para a democracia foi operada num contexto de paz social, com a retirada dos militares para os quartéis em vista do fracasso da "revolução" em promover o desenvolvimento social no contexto da modernização. O Estado autoritário colocou-se acima das classes por meio de mecanismos de violência, cuja característica central foi seu caráter institucionalizado em suas duas modalidades, a violência física e a violência simbólica. Nesse sentido, o Estado autoritário careceu de entrada junto à massa da população, tendo em vista o fato de o Estado conduzir a sociedade num modelo tecnocrático, com forte poder por parte da burocracia militar. Sem operar com âncoras em relação à sociedade civil, o Estado autoritário terminou por arrefecer os mecanismos de violência, gestando, internamente, a mudança para um regime democrático que, como no estilo autoritário, surgiu sem grandes mobilizações, na calada do tempo. 


\section{Referências Bibliográficas}

ALVES, Maria Helena Moreira (1984) - Estado e Oposição no Brasil (1964-1984). Petrópolis: Vozes.

AQUINO, Maria Aparecida (2004) - Estado Autoritário Brasileiro Pós-64. Conceituação, Abordagem Historiográfica, Ambigüidades e Especificidades. In: 1964-2004. 40 Anos do Golpe. Ditadura Militar e Resistência no Brasil. Rio de Janeiro: FAPERJ, 7 Letras.

BORGES FILHO, Nilson (2003) - A Doutrina da Segurança Nacional e os Governos Militares. In: FERREIRA, Jorge \& DELGADO, Lúcilia de Almeida Neves (orgs.) O Brasil Republicano: O Tempo da Ditadura. Rio de Janeiro: Civilização Brasileira, vol. IV.

CARDOSO, Femando Henrique (1982) - Os Regimes Autoritários na América

Latina. In: O Novo Autoritarismo na América Latina. Rio de Janeiro: Paz e Terra. COELHO, Edmundo Campos (1976) - Em Busca da Identidade. O Exército e a

Política da Sociedade Brasileira. Rio de Janeiro: Forense-Universitária.

CORRÊA, Arsênio (1997) - A Ingerência Militar na República e no Positivismo.

Rio de Janeiro: Editora Expressão e Cultura.

FAUSTO, Boris (2001a) - O Pensamento Nacionalista Autoritário. Rio de Janeiro: Jorge Zahar Editor.

FAUSTO, Boris (2001b) - História do Brasil. São Paulo: EDUSP.

FERREIRA, Oliveiras S. (2000) - Vida e Morte do Partido Fardado. São Paulo: Editora Senac.

FIGUEIREDO, Lucas (2005) - Ministério do Silêncio. A História do Serviço Secreto Brasileiro de Washington Luís a Lula. 1927-2005. Rio de Janeiro: Record.

GASPARI, Elio (2004)-A Ditadura Encurralada. São Paulo: Companhia das Letras. GÓES, Walder (1984) - O Novo Regime Militar no Brasil. In: Dados - Revista de Ciências Sociais, vol. 27 n $^{\circ} 3$.

GUIMARÃES, César (2001) - Vargas e Kubitscheck: A Longa Distância entre a Petrobrás e Brasília. In: CARVALHO, Maria Alice Rezende de (org.). República no Catete. Rio de Janeiro: Museu da República.

LEAL, Victor Nunes (1997) - Coronelismo, Enxada e Voto. Rio de Janeiro: Editora Nova Fronteira.

LESSA, Renato (2001) - A Invenção da República no Brasil: Da Aventura à Rotina. In: CARVAlHo, Maria Alice Rezende de (org.). República no Catete. Rio de Janeiro: Museu da República.

LIMA SOBRINHO (1975) - A Verdade Sobre a Revolução de Outubro - 1930.

São Paulo: Alfa-Ômega. 
MACEDO Ubiratan Borges de (1979) - Revista Convivium, vol. XXI, outubro.

O’DONNELL, Guillermo (1986) - Contrapontos. Autoritarismo e Democratização. São Paulo: Vértice.

O’DONNELL, Guillermo ( 1987) - Reflexões Sobre o Estado Burocrático-Autoritário. São Paulo: Vértice.

RAMOS, Guerreiro (1963) - Mito e Verdade da Revolução Brasileira. Rio de Janeiro: Zahar Editores.

ROLLEMBERG, Denise (2003) - Esquerdas Revolucionárias e Luta Armada, In: FERREIRA, Joige \& DELGADO, Lúcilia de Almeida Neves (orgs.) O Brasil Republicano: O Tempo da Ditadura. Rio de Janeiro: Civilização Brasileira, vol. IV.

SANTOS, Wanderley Guilherme dos (1986) -1964: Anatomia da Crise. São Paulo: Vértice.

SANTOS, Wanderley Guilherme dos (1998) - Décadas de Espanto e uma Apologia Democrática. Rio de Janeiro: Rocco.

SCHWARTZMAN, Simon (1982) - Bases do Autoritarismo Brasileiro. Rio de Janeiro: Campus.

SOARES, Gláucio Ary Dillon (1973)- Sociedade e Política no Brasil. Desenvolvimento, Classe e Política Durante a Segunda República. São Paulo: Difel (Coleção Corpo e Alma do Brasil, XXXVIII).

SODRÉ, Nelson Wemeck (1962) - Formação Histórica do Brasil. São Paulo: Brasiliense.

TREVISAN, Leonardo (1985) - O Pensamento Militar Brasileiro. São Paulo: Global.

VIANNA, Oliveira (1982) - Instituições Políticas Brasileiras. Belo Horizonte: Itatiaia.

WERNECK VIANNA, Luiz (1999) - Liberalismo e Sindicato no Brasil. Belo Horizonte: Editora da UFMG.

WERNECK VIANNA, Luiz (2001) - O Estado Novo e a "Ampliação" Autoritária da República. In: CARVALHO, Maria Alice Rezende de (org.) - República no Catete. Rio de Janeiro: Museu da República. 